CLINICAL STUDY

\title{
Germline inactivating mutations of the aryl hydrocarbon receptor-interacting protein gene in a large cohort of sporadic acromegaly: mutations are found in a subset of young patients with macroadenomas
}

\author{
Laure Cazabat $^{1,2,3}$, Rossella Libè $e^{1,2,3,4}$, Karine Perlemoine ${ }^{1,2,3}$, Fernande René-Corail ${ }^{1,2,3}$, Nelly Burnichon ${ }^{3,5}$, \\ Anne-Paule Gimenez-Roqueplo ${ }^{3,5}$, Laurence Dupasquier-Fediaevsky ${ }^{9}$, Xavier Bertagna ${ }^{1,2,3,6}$, Eric Clauser ${ }^{1,2,3}$, \\ Philippe Chanson ${ }^{7,8}$, Jérôme Bertherat ${ }^{1,2,3,6}$ and Marie-Laure Raffin-Sanson ${ }^{1,2,3,9,10}$ \\ ${ }^{1}$ INSERM, U567, 75 Paris, France, ${ }^{2}$ Institut Cochin, Université Paris Descartes, CNRS (UMR8104), 75 Paris, France, ${ }^{3}$ Faculté de Médecine René \\ Descartes, Université Paris 5, Paris F-75014, France, ${ }^{4}$ Assistance Publique Hôpitaux de Paris, Hôpital Cochin, Unité d'Oncogénétique, 75 Paris, France, \\ ${ }^{5}$ Département de Génétique, Assistance Publique Hôpitaux de Paris, Hôpital Européen Georges Pompidou, Paris, France, ${ }^{6}$ Département d'Endocrinologie, \\ Assistance Publique Hôpitaux de Paris, Hôpital Cochin, Paris, France, ${ }^{7}$ Département d’Endocrinologie, Assistance Publique Hôpitaux de Paris, Hôpital \\ Bicêtre, Le Kremlin-Bicêtre, France, ${ }^{8}$ Faculté de Médicine de Bicêtre, Université Paris Sud, 94 Le Kremlin Bicêtre, France, ${ }^{9}$ Département d'Endocrinologie, \\ Assistance Publique Hôpitaux de Paris, Hôpital Ambroise Paré, 92 Boulogne, France and ${ }^{10}$ Faculté de Médecine Paris-Ile de France Ouest, Université de \\ Versailles Saint-Quentin-en-Yvelines, 10 Garches, France
}

(Correspondence should be addressed to M-L Raffin-Sanson who is now at Unité d'Endocrinologie, Hôpital Ambroise Paré, 92240 Boulogne, France; Email: marie-laure.raffin-sanson@apr.aphp.fr)

\begin{abstract}
Objective: Germline mutations of the aryl hydrocarbon receptor-interacting protein gene (AIP) have recently been described in three families with $\mathrm{GH}$ or prolactin-secreting tumors, as well as in a few patients with apparently sporadic somatotropinomas. The aim of the study was to determine the prevalence of AIP mutations in a large cohort of patients with apparently sporadic GH-secreting tumors. Design: One hundred and fifty-four patients were included in a prospective cohort designed to study the genetic predisposition to GH-secreting tumors together with 270 controls.

Methods: In all these subjects, the entire coding sequence of the AIP gene was screened for germline mutations.

Results: AIP mutations were detected in 5 out of 154 patients (3\%): nonsense mutations in exon 4 (p.Lys201X; $n=2$ ) and in exon 6 (p.Arg304X), one deletion in exon 3 (c.404delA; pHis135LeufsX21), and one mutation affecting the splice acceptor site of exon 4 (c.469-2 A>G). The five patients with an AIP mutation were significantly younger (mean age \pm s.D.: $25 \pm 10$ vs $43 \pm 14$ years, $P=0.005$ ) and three of them presented with gigantism. One missense mutation (p.Arg304Gln) was found in a single patient that was absent in all controls.

Conclusions: Germline mutations of the AIP gene were found in a small proportion of patients with sporadic pituitary somatotropinomas. This study shows that age and gigantism are simple clinical features which can help to select patients for mutation screening. It also supports the role of AIP in pituitary tumorigenesis.

European Journal of Endocrinology 157 1-8
\end{abstract}

\section{Introduction}

Somatotrope tumors are rare pituitary neoplasms, responsible for growth hormone $(\mathrm{GH})$ hypersecretion causing acromegaly in adult patients and gigantism when GH oversecretion occurs before the closure of epiphyseal growth plates. Although it may cause severe symptoms, including cardiac manifestations, and increase mortality from cancer, this condition is difficult to diagnose early whereas treatment of advanced or aggressive tumors may be difficult (1). The large majority of these tumors are sporadic, arising from a somatic mutation in a somatotrope cell allowing clonal expansion. The most frequent somatic molecular alterations identified to date are gainof-function mutations in the guanine nucleotide-binding $\alpha$-subunit 1 gene, encountered in about one-third of the tumors. They lead to constitutive activation of the adenylyl cyclase, cellular proliferation, and GH hypersecretion. However, in many tumors, no Gs $\alpha$ mutations are found, even if cAMP-dependent pathways are activated, indicating that other unknown mechanism(s) of cAMP activation must exist in sporadic somatotrope tumors. Other molecular defects have been reported such as pituitary tumor-transforming gene overexpression $(2,3)$.

A small proportion of GH-secreting adenomas occur with a familial aggregation, as a component of either 
the multiple endocrine neoplasia type 1 (MEN1) or the Carney complex, both syndromes resulting in a genetic predisposition to multiple endocrine tumors $(4,5)$. Isolated familial pituitary tumors were also described in the absence of MEN1 and PRKAR1A mutations (6). These syndromes require further genetic characterization. Recently, Vierimaa et al. (7) identified germlineinactivating mutations of the aryl hydrocarbon receptor-interacting protein gene (AIP, also called $X A P 2$ or ARA9) in three kindreds with pituitary prolactin- and/or GH-secreting adenomas. Heterozygous mutations of the same gene were also found in $\sim 10 \%$ of Finnish patients diagnosed with apparently sporadic somatotropinomas. It is noteworthy that, even in families, only a few members were diagnosed with prolactin or GH hypersecretion, suggesting that AIP is a low-penetrance tumor susceptibility gene. Because of this low penetrance, inherited predisposition to AIP may be difficult to detect by patient interviews.

We had previously collected germline DNA and bioclinical data from a prospective cohort of 154 consecutive patients with GH-producing pituitary tumor with no family history of pituitary tumor, MEN1 or Carney complex. This cohort is part of a program designed to study the potential genetic factors involved in the genesis of apparently sporadic GH-secreting pituitary tumors. In the present study, this cohort was studied to determine the prevalence of germline mutations of the AIP gene and the clinical characteristics associated with AIP mutations. We found five heterozygous inactivating mutations of the AIP gene and one missense mutation absent from 270 matched controls. This supports the role of AIP in the development of a subset of apparently sporadic pituitary tumors.

\section{Patients and methods}

\section{Patients and controls}

One hundred and fifty-four consecutive patients investigated for a GH-secreting pituitary adenoma in the Endocrine Departments of Cochin and Bicêtre Hospitals were prospectively included in a population cohort between December 2002 and September 2006. Patients with a family history of pituitary tumor or clinical features suggesting McCune Albright syndrome, Carney complex or MEN1 were excluded after examination by a senior endocrinologist. Patients were specifically asked for pituitary tumors symptoms among their family; we thus considered them as apparently sporadic acromegaly. However, none of the relatives have been directly interviewed or clinically examined. Clinical data (height, weight, thyroid palpation, age at time of diagnosis, and birth place), biochemical data before any treatment (basal and nadir plasma GH levels during oral glucose test, insulin-like growth factor-I (IGF-I)), as well as morphological data (adenoma size), and histological findings after transsphenoidal surgery were collected.
Two hundred and seventy control subjects were also recruited by the same investigators. In controls, age, medical history, and birthplace were recorded. A clinical examination was performed in order to exclude subjects with personal or family history of MEN1 or Carney complex. All subjects gave informed consent to genetic studies and the protocol was approved by the Institutional Review Board of Cochin Hospital.

\section{DNA extraction and PCR amplification}

Genomic DNA was prepared from blood samples as previously described (9). For patients and controls, the six exons and the flanking intronic sequences of the AIP gene (GenBank accession number Hs. 412433) were amplified by PCR using the following specific primers:

exon 1 sense 5'-CTA GGA GTT GCC GAA GCA AG-3', $^{\prime}$ antisense 5'-AAA CCC AGA TAC CCG AGG AC-3';
exon 2 sense 5'-GGA CTG GAC TTC TCC TTG GG-3',
antisense 5'-GTC TAG CAG AGG GTG GAG GG-3';
exon 3 sense 5'-AGG GGG TTA GGT GCT CTG TT-3',
antisense 5'-GTT TCC TGG AGG AGG TGA CA-3';
exons $4-5$ sense 5'-CTC TGC TGC TGG TGT GTG AT-3',
antisense 5'-ATT CAT GCT TCA TTG GCA CA-3'; and
exon 6 sense 5'-CCA ATG AAG CAT GAA TGG TG-3',
antisense 5'-AAC AGC CAC CCA AGT ACC AG-3'.

The PCR conditions were: denaturation at $95^{\circ} \mathrm{C}$ for $5 \mathrm{~min}$, followed by 35 cycles of $1 \mathrm{~min}$ at $95^{\circ} \mathrm{C}, 1 \mathrm{~min}$ at $60{ }^{\circ} \mathrm{C}$ and $1 \mathrm{~min}$ at $72{ }^{\circ} \mathrm{C}$, and a final extension step of $8 \mathrm{~min}$ at $72{ }^{\circ} \mathrm{C}$. Direct sequencing of the purified fragments was performed using the Genetic Sequencer ABI3100 AppliedBiosystems apparatus (Foster City, CA, USA). All genetic alterations were confirmed by a second PCR and direct sequencing. The amplification and sequencing of genomic DNA for all of the coding sequences of Menin and PRKAR1A genes were realized in the same manner. Primers are available upon request.

\section{Statistical analysis}

Clinical, biochemical, and radiological data were recorded in a Microsoft Access 98 computerized database. Analyses included Student's $t$-test, $\chi^{2}$-test and ANOVA, which were all carried out with the SAS package (SAS Institute Inc., Cary, NC, USA).

\section{Results}

\section{Clinical, hormonal, and radiological data in acromegalic patients}

The 154 patients ( 84 females and 70 males) were aged 15-79 years at the time of diagnosis, with a mean age of $42.6 \pm 14.3$ years (mean \pm S.D). Eighty percent of the patients were French Caucasians whereas the remaining 
had diverse ethnic origins. Anthropometric measures were as indicated: height $=171 \pm 10.5 \mathrm{~cm}$, weight $=$ $83.4 \pm 20.6 \mathrm{~kg}$, body mass index $(\mathrm{BMI})=28 \pm 5.4$. Basal plasma $\mathrm{GH}$ levels $=66.3 \pm 91.3 \mathrm{ng} / \mathrm{ml}$, nadir $\mathrm{GH}$ during oral glucose load $=29.1 \mathrm{ng} / \mathrm{ml}$, with a very large dispersion, ratio between patient plasma IGF-I level and the upper limit of normal for age $=2.97 \pm 1.45$. Twentythree patients had microadenomas whereas 92 tumors were $10 \mathrm{~mm}$ or larger. The mean adenoma size was $18.8 \pm 11.3 \mathrm{~mm}$ (Table 1 ).

\section{AIP mutations}

Four different mutations leading to premature stop codons or affecting a splice acceptor site were identified in 5 out of 154 acromegalic patients (Table 1): a one nucleotide deletion in exon 3 (c.404delA; p.His135Leufs21X) leading to a frameshift and a premature stop codon after 19 amino acids (patient 1); a nonsense mutation in exon 4 (p.Lys201X) found in two unrelated patients (patients 3 and 4); a nonsense mutation in exon 6 (p.Arg 304X, patient 5) which has already been described in two apparently unrelated Italian families $(7,8$; patient 5 and his parents were born in France). The last mutation is located in the splice acceptor site of exon 4 (c.469-2 A>G, patient 2). None of these mutations were observed in the 270 controls. Thus, the overall frequency is 3\%, 95\% confidence interval is $1-7 \%$. The difference is statistically significant with a $P=0.0061$. The frequency rises to $12.5 \%$ (4 out of 32 ) considering only patients under 30 years (Figs 1 and 2 ).

\section{Clinical data in patients with AIP mutations}

Patient 1 Male, presented at 14 years of age, complaining of excessive growth: $188 \mathrm{~cm}$, whereas his mother and father were 163 and $168 \mathrm{~cm}$ tall respectively. Diagnosis of gigantism because of $\mathrm{GH}$ excess was established and surgical ablation of a pituitary macroadenoma was performed, followed by radiotherapy because of persistent GH hypersecretion. After 30 years, GH hypersecretion is well controlled but panhypopituitarism has developed. He has one son without known endocrine abnormality (Table 1).

Patient 2 Male, GH hypersecretion was diagnosed at the age of 40 years because of headaches, morphological changes, sweating, and bilateral carpal tunnel syndrome; all symptoms had been noticed for at least 3 years. Hormonal and morphological data are shown in Table 1. After surgical treatment, somatostatin analog treatment was indicated because of persistent GH hypersecretion. Immunostaining was positive for prolactin and GH. After 15 years, GH secretion is still under control with octreotide acetate LAR $10 \mathrm{mg} / 2$ months. There is no hypopituitarism.

Patient 3 Female, presented at the age of 25 with secondary amenorrhea. At the age of 27, acromegaly was diagnosed because of morphological changes and headaches. Biochemical features were consistent with acromegaly. An enlarged sella was observed on skull $\mathrm{X}$-ray. She was treated by transsphenoidal surgery followed by radiotherapy. GH secretion was controlled but she developed panhypopituitarism. At the age of 41 , a $19 \mathrm{~mm}$ incidental nonhypersecreting adrenocortical adenoma was surgically removed. After 10 years, an ulcerative colitis was diagnosed. At the age of 58, thyroidectomy was performed because of a $4 \mathrm{~cm}$ nodule. Histology concluded to a microfollicular and trabecular adenoma. She is now aged 61 and GH secretion is still low.

Table 1 Clinical data of patients with aryl hydrocarbon receptor-interacting protein (AIP) germline mutation. The clinical, biological, and AIP sequence for the five patients with a germline AIP mutation are shown. The two last lines represent the mean clinical data of the patients without $A I P$ gene mutation and of the whole cohort.

\begin{tabular}{|c|c|c|c|c|c|c|c|c|c|}
\hline Patient no. & Sex & $\begin{array}{c}\text { Age at } \\
\text { diagnosis } \\
\text { (years) }\end{array}$ & $\begin{array}{l}\text { Height } \\
(\mathrm{cm})\end{array}$ & $\begin{array}{l}\text { Weight } \\
(\mathrm{kg})\end{array}$ & BMI & GH $(n g / m l)$ & $\begin{array}{l}\text { IGF-I (P/N } \\
\text { ratio) }\end{array}$ & $\begin{array}{l}\text { Tumor size } \\
(\mathrm{mm})\end{array}$ & Mutation \\
\hline 1 & M & 15 & 197 & 102 & 26.3 & NA & NA & NA (macro) & $\begin{array}{l}\text { c. } 404 \text { delA; } \\
\text { p. His 135Leufs } \\
\text { X21 }\end{array}$ \\
\hline 2 & M & 40 & 173 & 80 & 26.7 & 33 & 2.5 & 15 & c. $469-2 A>G$ \\
\hline 3 & $\mathrm{~F}$ & 27 & 157 & 63 & 25.6 & 100 & NA & NA (macro) & p.Lys201X \\
\hline 4 & M & 24 & 189 & 130 & 36.4 & NA & NA & NA (macro) & p.Lys201X \\
\hline 5 & $\mathrm{M}$ & 17 & 195 & 95 & 36.8 & 12 & NA & NA (macro) & p.Arg304X \\
\hline $\begin{array}{l}\text { AIP non- } \\
\quad \text { mutated } n=149\end{array}$ & $\begin{array}{l}83 \mathrm{~F} \\
66 \mathrm{M}\end{array}$ & $42.6 \pm 14$ & $\begin{array}{l}164.5(\mathrm{~F}) \\
178.3(\mathrm{M})\end{array}$ & $\begin{array}{l}74.6(\mathrm{~F}) \\
93.7(\mathrm{M})\end{array}$ & $\begin{array}{l}27.5(\mathrm{~F}) \\
29.1(\mathrm{M})\end{array}$ & 51.8 (14 NA) & $3(42 \mathrm{NA})$ & 18 (24 NA) & \\
\hline $\begin{array}{l}\text { Whole cohort } \\
\quad n=154\end{array}$ & $\begin{array}{l}84 \mathrm{~F} \\
70 \mathrm{M}\end{array}$ & $43.2 \pm 14.1$ & $\begin{array}{l}164.4(\mathrm{~F}) \\
178.9(\mathrm{M})\end{array}$ & $\begin{array}{c}74.5(\mathrm{~F}) \\
93(\mathrm{H})\end{array}$ & $\begin{array}{l}27.5(\mathrm{~F}) \\
29.3(\mathrm{M})\end{array}$ & 51.7 (16 NA) & 2.99 (46 NA) & $18(28 \mathrm{NA})$ & \\
\hline
\end{tabular}

Sex, age at diagnosis, height, weight, body mass index (BMI), basal GH value, ratio between patient plasma IGF-I level and the upper limit of normal for age $(\mathrm{P} / \mathrm{N})$, tumor size and mutation are reported. NA, not available. 

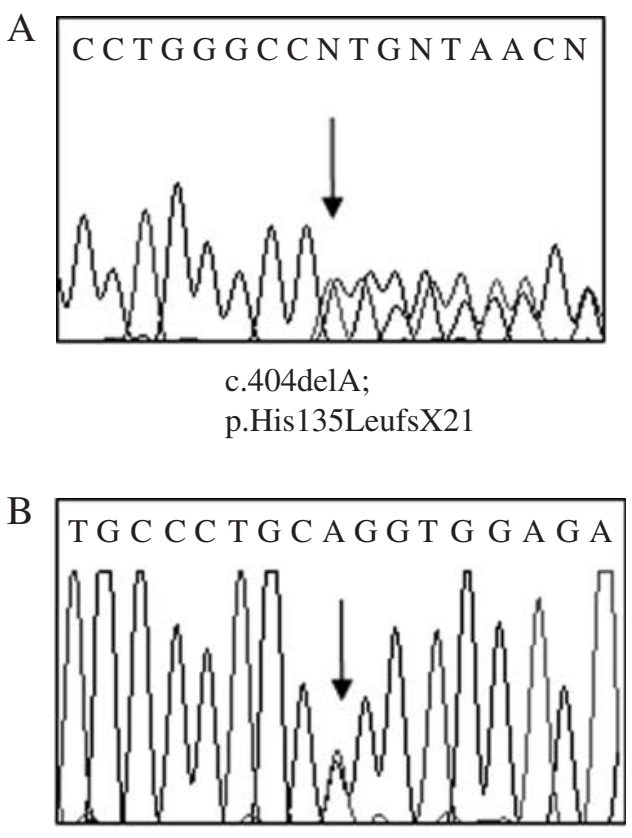

c. $469-2$ A $>$ G

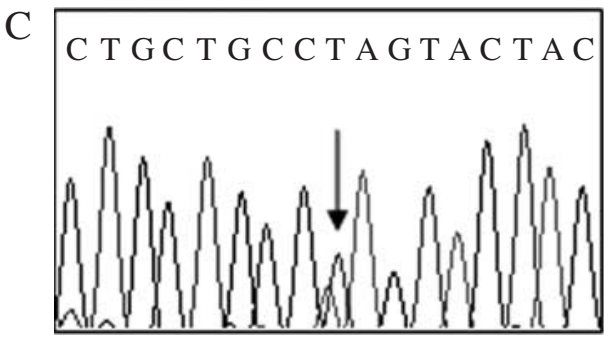

p.Lys $201 \mathrm{X}$

$\mathrm{D}$

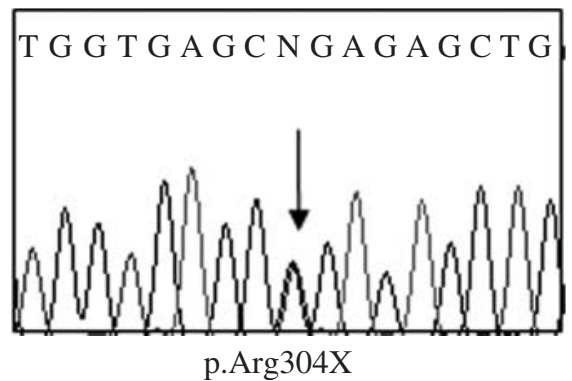

Figure 1 AIP germline mutations found in the cohort of 154 consecutive sporadic acromegalic patients. (A) Mutation of patient 1: single base pair deletion in exon 3 (c.404delA; p.His135LeufsX21); (B) mutation of patient 2: point mutation in exon 4 splice site (c.469-2 $A>G$ ); (C) mutation of patients 3 and 4 : nonsense mutation in exon 4 (p.Lys201X); and (D) mutation of patient 5: nonsense mutation in exon 6 (p.Arg304X).

Patient 4 Male, presented at the age of 24 with severe headaches and visual impairment revealing a compressive pituitary tumor. No preoperative hormonal data are available. A somatotrope macroadenoma was partially removed by emergency transcranial surgery. Postoperatively, GH hypersecretion was diagnosed. His height suggested gigantism. The treatment was complemented by transsphenoidal resection of remaining tissue followed by radiotherapy. At the age of 38 , he was operated for massive pulmonary embolism. At the age of 41 , he developed a hemorrhagic stroke. Thereafter, GH secretion was controlled but the patient developed panhypopituitarism and severe obesity.

Patient 5 Male, presented at the age of 17 with headaches, visual field defect, and a height suggesting gigantism. A pituitary magnetic resonance imaging (MRI) scan showed a $15 \mathrm{~mm}$ pituitary macroadenoma. Acromegaly was confirmed by hormonal data without hyperprolactinemia. Transsphenoidal surgery was performed allowing complete cure of $\mathrm{GH}$ hypersecretion. Immunostaining was positive for GH. Twenty years after surgery, GH is normalized without any pituitary deficiency but he suffers from severe obesity (BMI: 37.2) complicated by diabetes mellitus and hypertension.

Patients with AIP mutations are significantly younger at the time of diagnosis $(24.6 \pm 9.9 ; P=0.005)$; men are also taller $(188.5 \mathrm{~cm})$, although the difference did not reach significance $(P=0.09)$. We noted three cases of gigantism out of five patients with germline AIP mutations, whereas only 17 out of 149 unmutated patients presented with gigantism $(P=0.016)$. Tumor size and hormonal data, especially plasma IGF-I levels are not available in four patients diagnosed before 1980. Four mutated patients were male and only one was female. However, the difference in sex ratio did not reach significance $(P=0.12)$.

\section{Missense mutations, polymorphism, and genetic variants}

A missense mutation in exon 6 was observed in one acromegalic patient (p.Arg304Gln) and was absent from the 270 control subjects; this mutation has also been described in one young Polish patient diagnosed with Cushing's disease, and an Italian acromegalic patient (10). This patient (female) presented at the age of 37 with severe headache, diplopia, and visual impairment revealing a compressive pituitary tumor. No preoperative hormonal data are available. Cerebral MRI found pituitary apoplexia. A somatotrope macroadenoma was partially removed by emergency surgery. Eighteen years after surgery, GH secretion is still under control using a somatostatin analog but she developed thyrotrope, corticotrope, and gonadotrope deficiencies and suffers from morbid obesity (BMI: 65.5) complicated by diabetes mellitus, sleep apnea, and hypertension. Four patients and two controls displayed nucleotide variations in the $3^{\prime}$ untranslated region: c. $993+34 \quad \mathrm{C}>\mathrm{G} \quad(n=1)$, c. $993+56 \mathrm{C}>\mathrm{G}(n=4)$, and c. $993+60 \mathrm{G}>\mathrm{A}(n=1)$. 


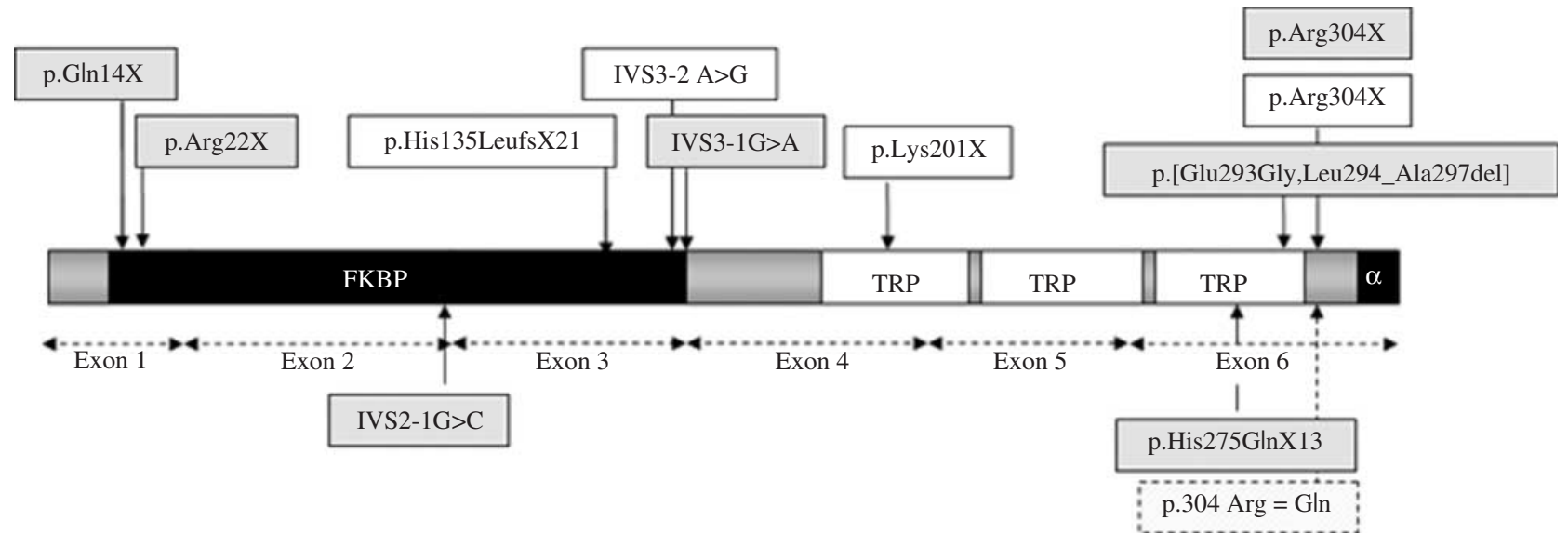

Figure 2 Schematic of aryl hydrocarbon receptor-interacting protein (AIP) with the functional domains and exon boundaries. Nonsense mutations are shown in white boxes and the missense mutation in a shaded line. Previously described mutations in apparently sporadic cases are indicated in gray boxes. FKBP, FK506-binding protein homology region; TRP, tetratricopeptide repeats; $\alpha, \alpha$ helix necessary for AHR binding.

A nonsynonymous mutation exon 1 (p.Arg16His, c.47 $\mathrm{G}>\mathrm{A}$ ) was present in two patients and two controls; this nucleotide change has been found in a family with isolated familial somatotropinoma (8), an Italian acromegalic patient without somatic $\mathrm{LOH}$, unselected pituitary adenomas from US and Poland, and in a German control (10). Two other new polymorphisms were detected in patients: p.Gly12Gly (c.36 G>A) in exon $1(n=1)$ and p.Gln142Gln (c.429 G>A) in exon 3 $(n=1)$. A previously described single nucleotide polymorphism has been found in patients and controls with a similar frequency: c. $468+111 \mathrm{C}>\mathrm{T}$ (rs 4084113) with an allele frequency of $36 \%$ in patients and $34 \%$ in controls, c.516 C > T (p.Asp172Asp, rs 2276020) in 0.7 and $1.6 \%$ in patients and controls respectively (Table 2 ).

No abnormality of PRKAR1A and Menin coding sequences has been found in the 28 patients under 30 years old without AIP mutations.

\section{Discussion}

Recently, mutations in the AIP gene were identified in familial pituitary tumors (mostly GH-secreting adenomas) as well as in 5 out of 51 patients from Northern Finland with sporadic acromegaly $(7,8)$. As most patients lacked a strong family history of pituitary tumor, AIP could be a low-penetrance susceptibility gene to GH-secreting pituitary adenomas (7). As these results were observed in a particular population, we studied the prevalence of AIP germline mutations or specific polymorphisms in a cohort of 154 consecutive acromegalic patients with a different ethnic origin (mostly French Caucasians). Patients with a family history of pituitary tumors were excluded, and Menin and PRKAR1A gene mutations were excluded in all patients under 30 years old. We found heterozygous inactivating mutations in five of them. Although we cannot exclude undiagnosed familial cases, according to statistical analysis, a germline mutation of AIP could therefore be expected in $1-7 \%$ of all apparently sporadic acromegalic patients. Considering the significant number of patients and the fact that it is a prospective recruitment of consecutive patients from two major academic centers devoted to pituitary diseases, these results are likely to be very representative of acromegaly in France. The prevalence may be different in different populations. However, our results are in agreement with two recently published series $(10,11)$.

One other patient displayed a missense mutation in exon 6, changing a basic residue (Arg) to Gln, in a region involved in the aryl hydrocarbon receptor (AHR) binding (12). This arginine is rather conserved among species, although it is sometimes replaced by another basic amino acid, lysine. The same amino acid changes have been found in a young Polish patient with Cushing's disease, and an Italian acromegalic patient. The functional consequences should be evaluated. Unfortunately, tumoral DNA is not available to look for $\mathrm{LOH}$. Two patients and two controls displayed a nonsynonymous mutation in exon 1, changing a lysine for another basic amino acid, histidine (p.Arg16His, c.47 G>A). This nucleotide change has been found in a family with isolated familial somatotropinoma (8), an Italian acromegalic patient without somatic LOH, unselected pituitary adenomas from US and Poland, as well as in one healthy German control (10). We considered this change as a rare polymorphism, although we cannot exclude its pathogenic value (13).

This study is discordant with data from Yu et al. (14) who very recently reported no mutations of the AIP gene in 66 patients with pituitary tumors. However, a much smaller number of $\mathrm{GH}$-secreting adenomas were tested $(n=35)$, and only the three previously published mutations were looked for (14). In fact, there is no 
Table 2 Aryl hydrocarbon receptor-interacting protein mutation and polymorphisms in acromegalic patients. Each line corresponds to one genetic variant in acromegalic patients and in controls. For each genetic variant, coding sequence mutation and amino acid changes are reported. Nonsense and missense mutations in acromegalic patients only are in bold type. Allelic frequency and GenBank reference sequence are also given. New AIP mutations reported in this paper have been deposited in Genbank (nos EF553637-EF553639)

\begin{tabular}{|c|c|c|c|c|c|}
\hline Exons & $\begin{array}{c}\text { Change in DNA } \\
\text { sequence }\end{array}$ & $\begin{array}{l}\text { Change in protein } \\
\text { sequence }\end{array}$ & $\begin{array}{l}\text { Allelic frequency in } \\
\text { patients }\end{array}$ & $\begin{array}{l}\text { Allelic frequency in } \\
\text { controls }\end{array}$ & Database reference \\
\hline \multirow[t]{3}{*}{ Exon 1} & c. $36 \mathrm{G}>\mathrm{A}$ & p.Gly12Gly & 0.0033 & 0 & ND \\
\hline & c. $47 \mathrm{G}>\mathrm{A}$ & p.Arg16His & 0.0065 & 0.0041 & EF066510 \\
\hline & c. $68 \mathrm{G}>\mathrm{A}$ & p.Gly23Glu & 0 & 0.0020 & ND \\
\hline Exon 2 & c. $132 \mathrm{C}>\mathrm{T}$ & p.Asp44Asp & 0 & 0.0057 & RS 11822907 \\
\hline \multirow[t]{4}{*}{ Exon 3} & c. $280-81 \mathrm{G}>\mathrm{A}$ & & 0 & 0.0020 & ND \\
\hline & c.404 del A & p.His135LeufsX21 & 0.0033 & 0 & EF553637 \\
\hline & c. $429 \mathrm{G}>\mathrm{A}$ & p.Gln142GIn & 0.0033 & 0.0033 & ND \\
\hline & c. $468+111 \mathrm{C}>\mathrm{T}$ & & 0.3604 & 0.3876 & RS 4084113 \\
\hline \multirow[t]{4}{*}{ Exon 4} & c. $469-2 \mathrm{~A}>\mathrm{G}$ & Site splice & 0.0033 & 0 & EF553638 \\
\hline & c.516 C> T & p.Asp172Asp & 0.0067 & 0.0123 & RS 2276020 \\
\hline & c.601 A $>$ T & p.Lys201X & 0.0066 & 0 & EF553639 \\
\hline & c. $645+37 \mathrm{G}>\mathrm{A}$ & & 0.0033 & 0 & ND \\
\hline \multirow[t]{4}{*}{ Exon 5} & c. $682 \mathrm{C}>\mathrm{A}$ & p.Lys228GIn & 0.9675 & 0.9805 & RS 641081 \\
\hline & c. $720 \mathrm{C}>\mathrm{T}$ & p.Cys 240 Cys & 0 & 0.0018 & ND \\
\hline & c.783 C > T & p.Tyr261Tyr & 0 & 0.0018 & ND \\
\hline & c. $787+24 \mathrm{C}>\mathrm{T}$ & & 0 & 0.0018 & ND \\
\hline \multirow[t]{10}{*}{ Exon 6} & c.807 C> T & p.Phe269Phe & 0 & 0.0019 & ND \\
\hline & c. $891 \mathrm{C}>\mathrm{A}$ & p.Ala297Ala & 0 & 0.0019 & RS 35665586 \\
\hline & c. $896 \mathrm{C}>\mathrm{T}$ & p.Ala299Val & 0 & 0.0019 & EF203235 \\
\hline & c. $910 \mathrm{C}>\mathrm{T}$ & p.Arg304X & 0.0033 & 0 & AM236344 \\
\hline & c. $911 \mathrm{G}>\mathbf{A}$ & p.Arg304GIn & 0.0033 & 0 & EF203236 \\
\hline & c. $965 \mathrm{C}>\mathrm{T}$ & p.Ala322Val & 0 & 0.0037 & ND \\
\hline & $\mathrm{c} .987 \mathrm{C}>\mathrm{T}$ & p.Ser329Ser & 0.0000 & 0.0019 & ND \\
\hline & c. $993+34 \mathrm{C}>\mathrm{G}$ & & 0.0033 & 0 & ND \\
\hline & c. $993+56 \mathrm{C}>\mathrm{G}$ & & 0.0100 & 0.0019 & ND \\
\hline & c. $993+60 \mathrm{G}>\mathrm{A}$ & & 0 & 0.0019 & ND \\
\hline
\end{tabular}

ND, never reported in GenBank or Ensembl database.

evidence of high spot region for the AIP gene and all mutated patients from our cohort except one had a new mutation. This result points out the need for sequencing the whole gene when genetic testing is proposed.

The mechanism of tumorigenesis induced by AIP mutations remains hypothetical. Heterozygous inactivating mutations are likely to result in a lower expression of the AIP protein. Moreover, loss of the wild-type allele was detected in somatotropinomas from mutated Finnish patients (7), and in one French patient studied separately (13), suggesting a tumor suppressor gene mechanism. AIP is a 330 amino acid protein analog to steroid receptors associated immunophilins (15). AIP was shown to form a complex with the AHR and the heat shock protein $90 \mathrm{kDa}$ (HSP90; $(16,17))$. The $\alpha$-helical C terminus of AIP, which is outside the tetratricopeptide repeat (TRP) domain, is absolutely required for binding to AHR as shown by deletion of the C-terminal 5 amino acids (18). Thus, all the truncated proteins encoded by one of the mutated alleles described here are expected to lose their capacity to bind AHR. AHR is a ligandactivated transcription factor involved in response to hypoxemia, cellular differentiation, and cell cycle regulation (19). AHR may bind exogenous ligands, including carcinogenic and teratogenic hydrocarbons like dioxin (20). AHR may also be activated by cAMP via the protein kinase $\mathrm{A}$, which can direct the receptor to the nucleus and stimulate AHR-dependent gene expression (21). However, in this last case, AHR recruits different regulators than after dioxin binding, and exerts quite different effects on transcription (21).

AIP was also shown to bind the phosphodiesterase (PDE) 4A5 and attenuate its effect (22). PDEs form a superfamily of enzymes that hydrolyze cyclic nucleotides (23). PDE4A5 is a cAMP-specific isoform (24). Recently, mutations of PDE11A4 have been found in patients with Cushing's syndrome due to micronodular adrenal hyperplasia (25). Consequences of AIP inactivation on cAMP signaling deserves further studies.

Clinical data analysis reveals that mutated patients are younger, and several had gigantism. This confirms data from Vierimaa et al. (7) and Georgitsi et al. (10). Younger age is also a clinical characteristic of patients with familial isolated pituitary adenoma (6). However, in the present cohort, acromegaly was diagnosed at the age of 40 in one case. This questions the age cut-off for genetic screening for AIP mutation in sporadic acromegaly. It is noteworthy that four out of five patients with AIP mutations of this cohort are male. This differs from the sex ratio $(\sim 1: 1)$ of the patients without mutation. Although the difference does not reach significance, we also note in the pedigrees reported by Vierimaa et al. (7), a large male predominance in mutated patients (six out of seven). Since AIP is autosomic, this might suggest that 
AIP inactivation would be more oncogenic in males than females.

Genetic testing may be useful in young patients with acromegaly, even in the absence of family history, and could allow early diagnosis in relatives bearing the mutation, which is a potentially important advantage to improve outcome (26)

Germline mutations of the AIP gene are present in a small but significant proportion of patients with sporadic acromegaly, supporting a role - still to be determined - in somatotrope tumorigenesis. In the setting of genetic counseling, genetic testing could be proposed to the youngest patients in order to evaluate, among relatives, a population at high risk of developing pituitary tumors.

\section{Acknowledgements}

This work was supported by the Plan Hospitalier de Recherche Clinique (AOR01093). We thank Anabelle Venisse, Michèle Nigou, Brigitte Radenen-Bussiere, and Françoise Gary for their technical assistance. We gratefully acknowledge the patients and all participants to this study, the nurse staff (especially Patricia Raffray) for their valuable help, Pr. Joël Coste for statistical analysis, Dr Sylvie Salenave for her collaboration, Dr Michèle Kujas, Pr. Pierre Brousset, Dr Michèle Bernier, Dr MarieFrancine Gontier and Dr Frédérique Tissier for pathological evaluation, and Pr. Alain Calender for helpful discussion.

\section{References}

1 Melmed S. Medical progress: Acromegaly. New England Journal of Medicine $20063552558-2573$.

$2 \mathrm{Yu}$ R \& Melmed S. Oncogene activation in pituitary tumors. Brain Pathology $200111328-341$.

3 Levy A \& Lightman SL. Molecular defects in the pathogenesis of pituitary tumors. Frontiers in Neuroendocrinology $2003 \mathbf{2 4}$ 94-127.

4 Chandrasekharappa SC, Guru SC, Manickam P, Olufemi SE, Collins FS, Emmert-Buck MR, Debelenko LV, Zhuang Z, Lubensky IA, Liotta LA, Crabtree JS, Wang Y, Roe BA, Weisemann J, Boguski MS, Agarwal SK, Kester MB, Kim YS, Heppner C, Dong Q, Spiegel AM, Burns AL \& Marx SJ. Positional cloning of the gene for multiple endocrine neoplasia-type 1. Science 1997276 404-407.

5 Kirschner LS, Carney JA, Pack SD, Taymans SE, Giatzakis C, Cho YS, Cho-Chung YS \& Stratakis CA. Mutations of the gene encoding the protein kinase A type I- $\alpha$ regulatory subunit in patients with the Carney complex. Nature Genetics 200026 89-92.

6 Daly AF, Jaffrain-Rea ML, Ciccarelli A, Valdes-Socin H, Rohmer V, Tamburrano G, Borson-Chazot C, Estour B, Ciccarelli E, Brue T, Ferolla P, Emy P, Colao A, De Menis E, Lecomte P, Penfornis F, Delemer B, Bertherat J, Wemeau JL, De Herder W, Archambeaud F, Stevenaert A, Calender A, Murat A, Cavagnini F \& Beckers A. Clinical characterization of familial isolated pituitary adenomas. Journal of Clinical Endocrinology and Metabolism $2006913316-3323$.

7 Vierimaa O, Georgitsi M, Lehtonen R, Vahteristo P, Kokko A, Raitila A, Tuppurainen K, Ebeling TM, Salmela PI, Paschke R, Gundogdu S, De Menis E, Makinen MJ, Launonen V, Karhu A
\& Aaltonen LA. Pituitary adenoma predisposition caused by germline mutations in the AIP gene. Science $2006 \mathbf{3 1 2}$ 1228-1230.

8 Daly AF, Vanbellinghen JF, Khoo SK, Jaffrain-Rea ML, Naves LA, Guitelman MA, Murat A, Emy P, Gimenez-Roqueplo AP, Tamburrano G, Raverot G, Barlier A, De Herder W, Penfornis A, Ciccarelli E, Estour B, Lecomte P, Gatta B, Chabre O, Sabate MI, Bertagna X, Garcia Basavilbaso N, Stalldecker G, Colao A, Ferolla P, Wemeau JL, Caron P, Sadoul JL, Oneto A, Archambeaud F, Calender A, Sinilnikova O, Montanana CF, Cavagnini F, Hana V, Solana A, Delettieres D, Luccio-Camelo DC, Basso A, Rohmer V, Brue T, Bours V, Teh BT \& Beckers A. Aryl hydrocarbon receptor interacting protein gene mutations in familial isolated pituitary adenomas: analysis in 73 families. Journal of Clinical Endocrinology and Metabolism 200792 1891-1896.

9 Groussin L, Horvath A, Jullian E, Boikos S, Rene-Corail F, Lefebvre H, Cephise-Velayoudom FL, Vantyghem MC, Chanson P, ConteDevolx B, Lucas M, Gentil A, Malchoff CD, Tissier F, Carney JA, Bertagna X, Stratakis CA \& Bertherat J. A PRKAR1A mutation associated with primary pigmented nodular adrenocortical disease in 12 kindreds. Journal of Clinical Endocrinology and Metabolism 2006 91 1943-1949.

10 Georgitsi M, Raitila A, Karhu A, Tuppurainen K, Makinen MJ, Vierimaa O, Paschke R, Saeger W, van der Luijt RB, Sane T, Robledo M, De Menis E, Weil RJ, Wasik A, Zielinski G, Lucewicz O, Lubinski J, Launonen V, Vahteristo P \& Aaltonen LA. Molecular diagnosis of pituitary adenoma predisposition caused by aryl hydrocarbon receptor-interacting protein gene mutations. PNAS 2007104 4101-4105.

11 Iwata T, Yamada S, Mizusawa N, Golam HM, Sano T \& Yoshimoto $\mathrm{K}$. The aryl hydrocarbon receptor-interacting protein gene is rarely mutated in sporadic GH-secreting adenomas. Clinical Endocrinology 200766 499-502.

12 Kazlauskas A, Poellinger L \& Pongratz I. Two distinct regions of the immunophilin-like protein XAP2 regulate dioxin receptor function and interaction with hsp90. Journal of Biological Chemistry 2002 277 11795-11801.

13 Barlier A, Vanbellinghen JF, Daly AF, Silvy M, Jaffrain-Rea ML, Trouillas J, Tamagno G, Cazabat L, Bours V, Brue T, Enjalbert A \& Beckers A. Mutations in the aryl hydrocarbon receptor interacting protein gene are not highly prevalent among subjects with sporadic pituitary adenomas. Journal of Clinical Endocrinology and Metabolism $2007921952-1955$.

$14 \mathrm{Yu}$ R, Bonert V, Saporta I, Raffel LJ \& Melmed S. AIP variants in sporadic pituitary adenomas. Journal of Clinical Endocrinology and Metabolism 200691 5126-5129.

15 Carver LA, LaPres JJ, Jain S, Dunham EE \& Bradfield CA. Characterization of the $\mathrm{Ah}$ receptor-associated protein, ARA9. Journal of Biological Chemistry 1998273 33580-33587.

16 Carlson DB \& Perdew GH. A dynamic role for the Ah receptor in cell signaling? Insights from a diverse group of Ah receptor interacting proteins Journal of Biochemical and Molecular Toxicology 200216 317-325.

17 Carver LA \& Bradfield CA. Ligand-dependent interaction of the aryl hydrocarbon receptor with a novel immunophilin homolog in vivo. Journal of Biological Chemistry $19972 \mathbf{2 7 2}$ 11452-11456.

18 Bell DR \& Poland A. Binding of aryl hydrocarbon receptor (AhR) to AhR-interacting protein. The role of hsp90. Journal of Biological Chemistry $200027536407-36414$.

$19 \mathrm{Gu}$ YZ, Hogenesch JB \& Bradfield CA. The PAS superfamily: sensors of environmental and developmental signals. Annual Review of Pharmacology and Toxicology 200040 519-561.

20 Ema M, Ohe N, Suzuki M, Minura J, Sogawa K, Ikawa S \& Fujii-Kuriyama Y. Dioxin binding activities of polymorphic forms of mouse and human arylhydrocarbon receptors. Journal of Biological Chemistry $199426927337-27343$.

21 Oesch-Bartlomowicz B, Huelster A, Wiss O, Antoniou-Lipfert P, Dietrich C, Arand M, Weiss C, Bockamp E \& Oesch F. Aryl hydrocarbon receptor activation by cAMP vs. dioxin: divergent signaling pathways. PNAS 2005102 9218-9223. 
22 Bolger GB, Peden AH, Steele MR, MacKenzie C, McEwan DG, Wallace DA, Huston E, Baillie GS \& Houslay MD. Attenuation of the activity of the cAMP-specific phosphodiesterase PDE4A5 by interaction with the immunophilin XAP2. Journal of Biological Chemistry 2003278 33351-33363.

23 Conti M. Phosphodiesterases and cyclic nucleotide signaling in endocrine cells. Molecular Endocrinology 200014 1317-1327.

24 McPhee I, Pooley L, Lobban M, Bolger G \& Houslay MD. Identification, characterization and regional distribution in brain of RPDE-6 (RNPDE4A5), a novel splice variant of the PDE4A cyclic AMP phosphodiesterase family. Biochemical Journal 1995 310 965-974.

25 Horvath A, Boikos S, Giatzakis C, Robinson-White A, Groussin L, Griffin KJ, Stein E, Levine E, Delimpasi G, Hsiao HP, Keil M,
Heyerdahl S, Matyakhina L, Libe R, Fratticci A, Kirschner LS, Cramer K, Gaillard RC, Bertagna X, Carney JA, Bertherat J, Bossis I \& Stratakis CA. A genome-wide scan identifies mutations in the gene encoding phosphodiesterase 11A4 (PDE11A) in individuals with adrenocortical hyperplasia. Nature Genetics $2006 \mathbf{3 8}$ 794-800.

26 Holdaway IM, Rajasoorya CR, Gamble GD \& Stewart AW. Long-term treatment outcome in acromegaly. Growth Hormone and IGF Research 200313 185-192.

Received 20 March 2007

Accepted 23 April 2007 